\title{
Artifact Lead Signal by ECG Finding
}

National Cancer Institute

\section{Source}

National Cancer Institute. Artifact Lead Signal by ECG Finding. NCI Thesaurus. Code

C114162.

An electrocardiographic recording in which one or more leads display extraneous signals which do not represent cardiac electrical activity. (CDISC) 